\title{
Molecular characterization of sheeppox virus from outbreaks in Karnataka, India
}

\author{
K. Sumana ${ }^{1,2}$, Yogisharadhya Revanaiah ${ }^{1}$, R. Apsana ${ }^{1}$, Parimal Roy ${ }^{1}$ and G. B. Manjunatha Reddy ${ }^{1}$
}

1. Indian Council of Agricultural Research Institute-National Institute of Veterinary Epidemiology and Disease Informatics, Yelahanka, Karnataka, India; 2. Department of Microbiology and Biotechnology, Jain University, Bengaluru, Karnataka, India.

Corresponding author: G. B. Manjunatha Reddy, e-mail: gbmpatho@gmail.com

Co-authors: KS: sumana25390@gmail.com, YR: dryogish.vet@gmail.com, RA: drapsana@gmail.com, PR: parimalroy580@gmail.com

Received: 11-11-2019, Accepted: 16-01-2020, Published online: 28-02-2020

doi: www.doi.org/10.14202/vetworld.2020.386-391 How to cite this article: Sumana K, Revanaiah Y, Apsana R, Roy $P$, Reddy GBM (2020) Molecular characterization of sheeppox virus from outbreaks in Karnataka, India, Veterinary World, 13(2): 386-391.

\begin{abstract}
Aim: This study aimed to characterize sheeppox virus (SPPV) using the P32 gene of the Capripoxvirus (CaPVs).

Materials and Methods: Clinical samples of skin, scabs, and nasal swab from suspected outbreaks Horalagallu ( $\mathrm{n}=13$ ) and Gerahalli $(n=11)$ at Ramanagara district in Karnataka were collected. All the samples were initially subjected to genusspecific diagnostic polymerase chain reaction (PCR). The pooled clinical samples from each outbreak were also subjected to virus isolation. The isolates were confirmed by CaPVs genotyping PCR targeting the full-length P32 gene, followed by sequencing and phylogenetic analysis.

Results: The clinical signs and lesions varied from mild to severe degree with no specificity between age and sex. Specific cytopathic changes in cell morphology were observed in infected Vero cells from both outbreaks, which were confirmed by PCR. The complete P32 gene from two outbreaks was successfully amplified with the expected amplicon size of $1006 \mathrm{bp}$. The sequencing and phylogenetic analysis revealed that both the outbreaks were due to SPPV and shared high similarity with published SPPVs from Karnataka and other parts of India.

Conclusion: The current study showed that complete P32 gene-based genotypic PCR assay can be used for genetic characterization and molecular epidemiology of both sheeppox and goatpox diseases and also to differentiate the causative agents. The sequence analysis revealed $100 \%$ similarity among the two outbreak isolates suggesting the same strain of the virus and common source of infection for the outbreaks.
\end{abstract}

Keywords: goatpox, P32, polymerase chain reaction, phylogenetic analysis, sheeppox.

\section{Introduction}

Sheep and goats contribute greatly to the income of marginal and landless farmers of the farming community. India has the second largest population of goats (148.88 million) and fourth largest population of sheep ( 74.26 million) increased by $14.1 \%$ and $10.1 \%$, respectively, over the previous census [1]. There are many diseases which affect sheep and goats, among them sheeppox and goatpox are one of the major diseases and cause severe economic loss in terms of damage to skin/hide and wool, reduced milk yield, and mortality [2,3]. The disease in sheep and goat is caused by sheeppox virus (SPPV) and goatpox virus (GTPV), respectively. The viruses belong to the genus Capripoxvirus (CaPVs) of the family Poxviridae [4,5]. Sheep and goatpox disease is enzootic in Northern and Central Africa and in Asia including the Indian subcontinent [6,7]. The mortality

Copyright: Sumana, et al. Open Access. This article is distributed under the terms of the Creative Commons Attribution 4.0 International License (http://creativecommons.org/licenses/ by/4.0/), which permits unrestricted use, distribution, and reproduction in any medium, provided you give appropriate credit to the original author(s) and the source, provide a link to the Creative Commons license, and indicate if changes were made. The Creative Commons Public Domain Dedication waiver (http:// creativecommons.org/publicdomain/zero/1.0/) applies to the data made available in this article, unless otherwise stated. rate in a susceptible population of sheep and goatpox may reach up to $50 \%$ in adults and $100 \%$ in the young stock and morbidity rate can reach up to $100 \%$ [8]. Sheeppox and goatpox outbreaks are being increasingly reported from different parts of India [9].

The virions of Capripox are ovoid in shape with an average size of $294 \mathrm{~nm} \times 273 \mathrm{~nm}$. Their genome is linear, double-stranded DNA of $\sim 150 \mathrm{~kb}$, contains 156 putative genes with high adenine and thymine (AT) content of $73-75 \%$ and shares $96 \%$ nucleotide (nt) identity. Among the 156 open reading frames (ORFs), the conserved essential genes of replication, structure, and assembly are located in the middle region (ORFs 024 to 123) and terminal variable region (ORFs 01 to 023 and 124 to 156 ) responsible for virulence and host range functions [10]. All the CaPVs having a structural protein called P32, contain a major immunogenic determinant [11]. CaPVs are currently classified within the genus based on the animal species from which the viruses are isolated. However, some SPPV and GTPV isolates found to be caused infection in both sheep and goats $[12,13]$. As both SPPV and GTPV are antigenically closely related and show similar clinical signs hence, they cannot be differentiate based on serological methods [14]. Recent molecular studies have shown that CaPVs are phylogenetically and 
genetically distinct based on individual and whole-genome sequencing [15-17].

The present study was undertaken to differentiate and characterize the SPPV isolates from field outbreaks.

\section{Materials and Methods}

\section{Ethical approval}

Ethical approval was not necessary for this study. However, samples were collected as per the standard sample collection procedure without any unnecessary harm or stress to the animals.

\section{Outbreak history and sample collection}

The disease outbreaks were reported during March 2016 from two mixed unvaccinated flocks consisting of Horalagallu and Gerahalli villages of Ramanagara district, Karnataka. The flocks consisted of local breeds of sheep and goats of young and adult age groups of both the sex. The disease was observed only in sheep, but in goats, there were no signs of disease. The clinical samples of nasal swab, skin lesion, and scabs were collected and were transported to the laboratory.

\section{Virus isolation}

The skin scabs and nasal swabs were triturated with $1 \mathrm{ml}$ of sterile phosphate-buffered saline, followed by 3 times freeze-thawing. The triturate was incubated with an antibiotic and antimycotic solution for $1 \mathrm{~h}$ at $37^{\circ} \mathrm{C}$, followed by centrifugation at

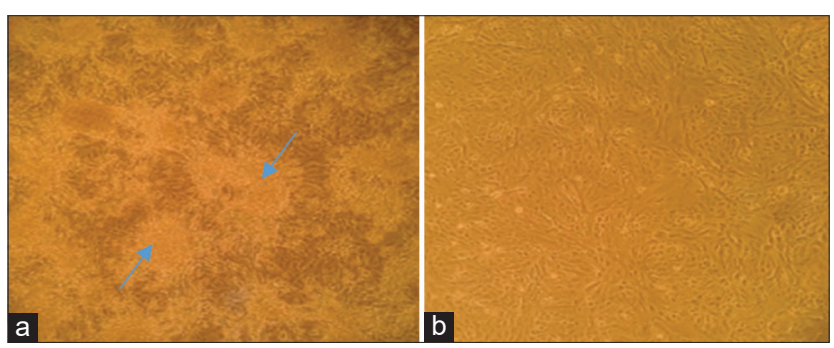

Figure-1: Virus isolation: Vero cells showing characteristic cytopathic effects such as rounding, clumping, and finally detachment of the cells were observed at seventh passage (a) compared to healthy (b).
$2000 \mathrm{rpm}$ for $10 \mathrm{~min}$. The supernatant was filtered with 0.45 -micron syringe filter. Approximately $500 \mu 1$ of inoculum was added to a confluent monolayer of Vero cells by $1 \mathrm{~h}$ adsorption method at $37^{\circ} \mathrm{C}$ to allow virus attachment; the inoculum was decanted and fresh maintenance medium (Dulbecco's Modified Eagle's Medium) was added. The cells were incubated at $37^{\circ} \mathrm{C}$ with $5 \% \mathrm{CO}_{2}$ and examined periodically. Infected flasks were given six blind passages at weekly intervals until cytopathic effect (CPE), which could be observed in seventh passage. The flasks showing CPE such as rounding, clumping, and detachment were freeze-thawed 3 times and were further processed for virus confirmation.

\section{DNA extraction and amplification}

The DNA was isolated from infected cells from both the outbreaks (Horalagallu-Nasal swab, GerahalliSkin scab) by DNeasy Blood and Tissue Kit (Qiagen, Germany), as per the manufacturing protocol. The purity and quantity of extracted DNA was determined by spectrophotometer. DNA was initially subjected to a diagnostic polymerase chain reaction (PCR) for the identification of genus-specific CaPVs by amplification of partial P32 gene for virus confirmation. Later same DNA samples were subjected to genotypic PCR by targeting full-length P32 gene (Table-1) [18,19]. The PCR was carried out $25 \mu 1$ reaction volume containing $12.5 \mu$ of Dream Taq Green PCR Master Mix (Thermo Fisher Scientific, USA), $10 \mathrm{pM}$ of each forward and reverse primer, $7.5 \mu \mathrm{l}$ of nuclease-free water, and $3 \mu \mathrm{l}$ of extracted DNA with following conditions of initial denaturation at $94^{\circ} \mathrm{C}$ for $5 \mathrm{~min}$, then 35 cycles of $94^{\circ} \mathrm{C}$ for $1 \mathrm{~min}, 57^{\circ} \mathrm{C}$ for $1 \mathrm{~min}$, and $72^{\circ} \mathrm{C}$ for $1 \mathrm{~min}$ followed by final extension at $72^{\circ} \mathrm{C}$ for $10 \mathrm{~min}$ in thermocycler (S1000 thermal cycler, Bio-Rad). The specific amplification was confirmed by agarose gel electrophoresis (1\% agar) using a gel documentation system (Syngene, Biodigital Pvt Ltd).

\section{Sequencing and phylogenetic analysis}

The gel slices containing PCR amplicons were purified using the GeneJET Gel Extraction

Table-1: List of primers used for partial and complete gene amplification of P32.

\begin{tabular}{llcccc}
\hline Primer name & Sequence $\left(\mathbf{5}^{\prime} \mathbf{- 3}^{\prime}\right)$ & Length & Tm ( $\left.{ }^{\circ} \mathbf{C}\right)$ & Product length (bp) & References \\
\hline SGPP32FP & ACACAGGGGGATATGATTTACC & 23 & 52 & 237 & {$[18]$} \\
SGPP32RP & ATACCGTTTTCATTCGTTAGC & 23 & & 1006 & {$[19]$} \\
B7-Forward & AACACTCTCATTGGTGTTCGG & 21 & 57 & & \\
A95-Reverse & CACATGGCAGATATCCCATTA & 21 & & & \\
\hline
\end{tabular}

Table-2: Animal population and disease prevalence of two outbreak flocks.

\begin{tabular}{|c|c|c|c|c|c|c|c|c|c|}
\hline \multirow[t]{3}{*}{ Animals } & \multicolumn{7}{|c|}{ Sheep } & \multirow{2}{*}{\multicolumn{2}{|c|}{$\begin{array}{c}\text { Goat details of } \\
\text { outbreak }\end{array}$}} \\
\hline & \multicolumn{3}{|c|}{ Details of outbreak } & \multicolumn{2}{|c|}{$\begin{array}{l}\text { Number of clinical } \\
\text { samples collected }\end{array}$} & \multicolumn{2}{|c|}{$\begin{array}{l}\text { Number of clinical } \\
\text { samples used }\end{array}$} & & \\
\hline & $\begin{array}{l}\text { Flock } \\
\text { size }\end{array}$ & Morbidity & Mortality & $\begin{array}{l}\text { Nasal } \\
\text { swab }\end{array}$ & $\begin{array}{l}\text { Skin } \\
\text { scab }\end{array}$ & $\begin{array}{l}\text { Nasal } \\
\text { swab }\end{array}$ & Skin scab & $\begin{array}{l}\text { Flock } \\
\text { size }\end{array}$ & Morbidity \\
\hline Flock: 1-horalagallu & 60 & 40 & 21 & 5 & 8 & 2 & 2 & 20 & 0 \\
\hline Flock: 2-gerahalli & 80 & 60 & 33 & 4 & 7 & 2 & 2 & 5 & 0 \\
\hline
\end{tabular}


Kit (Thermo Fisher Scientific, USA). The eluted products were cloned into pGEM-T vector cloning kit (Promega) and transformed into the top ten Escherichia coli cells. Blue-white screening was observed by adding X-gal $(100 \mathrm{mg} / \mu \mathrm{l})$ and Isopropyl $\beta$ - d-1-thiogalactopyranoside $(50 \mathrm{mg} / \mu \mathrm{l})$ on Luria Broth plate. Recombinant clones were confirmed by colony PCR using gene-specific primers. The plasmid
DNA was extracted using the plasmid DNA extraction kit (Thermo Fisher Scientific, USA) and sequenced (Eurofins, Bengaluru). The forward and reverse sequences were edited and submitted to GenBank. Sequences obtained from the current study and other GenBank sequences were aligned by ClustalW using the neighbor-joining method [20] and the phylogenetic tree was constructed using MEGA 10.0.5 [21].

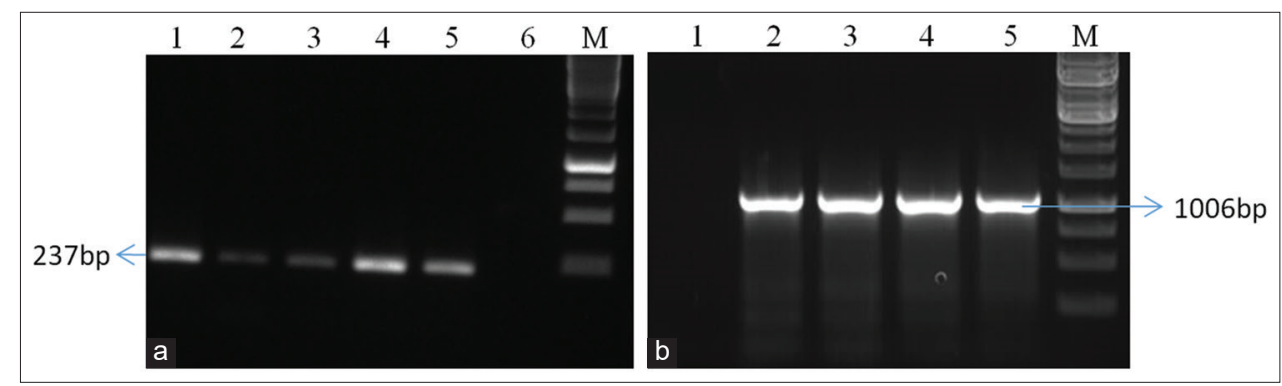

Figure-2: Agarose electrophoresis: The clinical samples were subjected to a partial P32 gene showing specific amplification at 237bp band. M-1kb marker, L1-L4 - outbreak samples, L5-positive control, and L6 Negative control (a). Isolated samples subjected to full-length P32 gene with specific amplification at 1006bp. M-1kb marker, L1 - Negative control, L2, and L3 - outbreak samples, L4 and L5 - positive control (b).

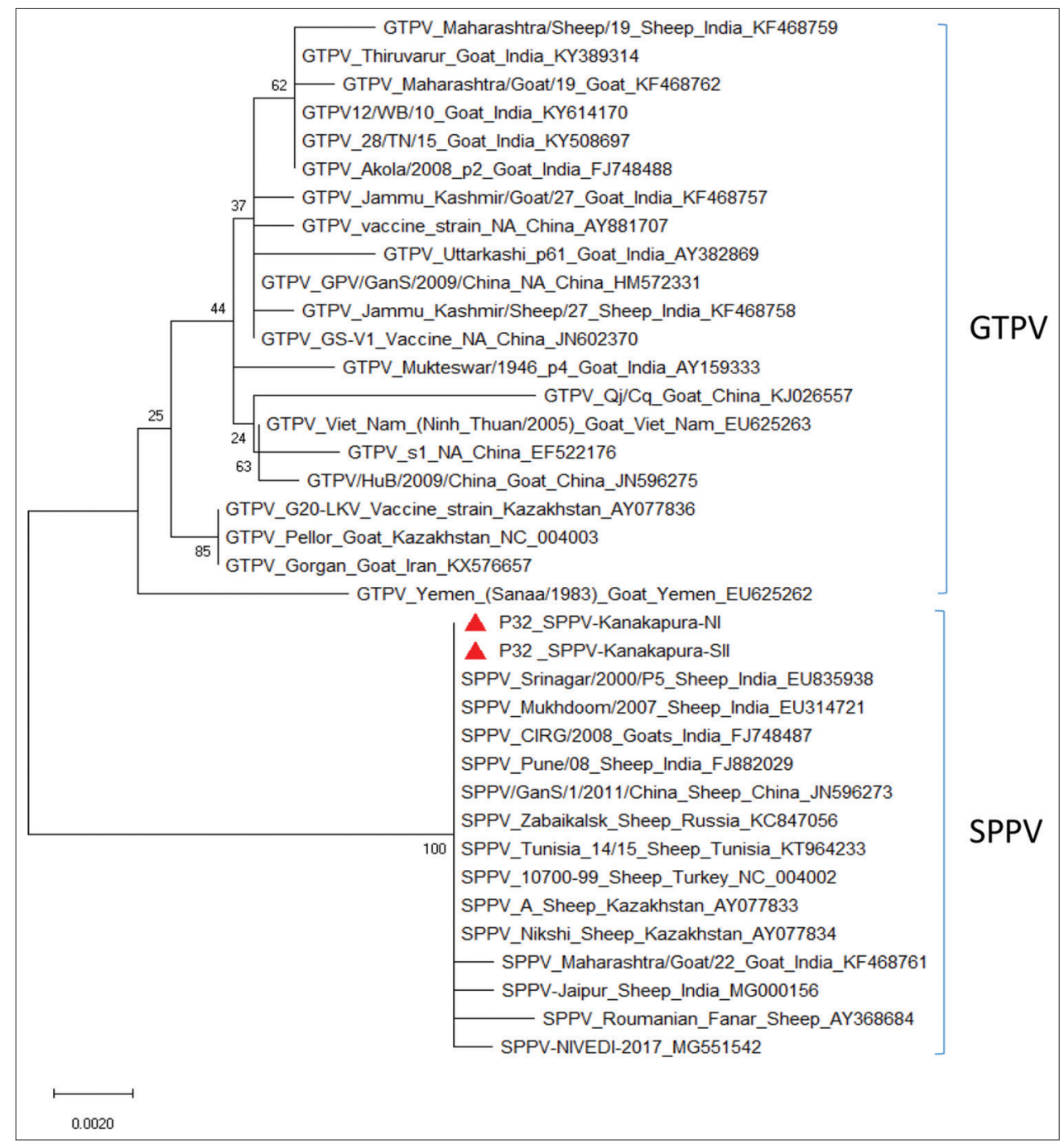

Figure-3: Phylogenetic tree: Phylogenetic tree based full-length P32 gene nucleotide sequence of sheeppox virus (SPPV) isolate from outbreak was carried out by the neighbor-joining program using MEGA version 10.0.5 (bootstrap 1000). Current outbreak sequences of SPPV were indicted by the red color triangle shape. 


\begin{tabular}{|c|c|}
\hline & 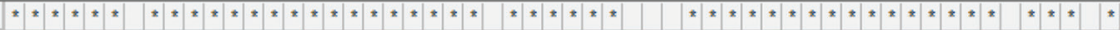 \\
\hline 1. P32_SPPV-Kanakapura-NI & TG TAAATTTTTTTTAAAAGATAAAAAAGATGATATCAGTTTATCATATAAGTTAC \\
\hline 2. P32_SPPV-Kanakapura-SII & T G TAAATTTTTTTTAAAAGATAAAAAAGATGATATCAGTTTATCATATAAGTTAC \\
\hline 3. SPPV-NNEDL-2017_MG551542 & 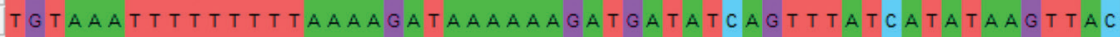 \\
\hline 4. SPPV_Srinagar/2000/PS_Sheep_India_EU835938 & T G TAAATTTTTTTTAAAAGATAAAAAAGATGATATCAGTTTATCATATAAGTTAC \\
\hline 5. SPPV_Roumanian_Fanar_Sheep_AY368684 & TG TAAATTTTTTTTAAAAGATAAAAAAGATGATATCAGTTTATCATATAAGTTAC \\
\hline 6. SPPV_Maharashtra/Goat/22_Goat_India_KF 468761 & TG TAAATTTTTTTAAAAGATAAAAAAGATGATATCAGTTTATCATATAAGTTAC \\
\hline 7. SPPV_Mukhdoom/2007_Sheep_India_EU314721 & TG TAAATTTTTTTAAAAGATAAAAAAGATGATATCAGTTTATCATATAAGTTAC \\
\hline 8. SPPV_CIRG/2008_Goats_India_FJ748487 & TG TAAATTTTTTTAAAAGATAAAAAAGATGATATCAGTTTATCATATAAGTTAC \\
\hline 9. SPPV/GanS/1/2011/China_Sheep_China_JN596273 & TGTAAATTTTTTTTAAAAGATAAAAAAGATGATATCAGTTTATCATATAAGTTAC \\
\hline 10. SPPV_Jaipur_Sheep_India_MG000156 & T G TAAATTTTTTTTAAAAGATAAAAAAGATGATATCAGTTTATCATATAAGTTAC \\
\hline 11. SPPV_Nikshi_Sheep_Kazakhstan_AY077834 & TGTAAATTTTTTTTAAAAGATAAAAAAGATGATATCAGTTTATCATATAAGTTAC \\
\hline 12. SPPV_A_Sheep_Kazakhstan_AY077833 & T G TAAATTTTTTTTAAAAGATAAAAAAGAT \\
\hline 13. SPPV_Pune/08_Sheep_India_FJ882029 & T G TAAATTTTTTTTAAAAGATAAAAAAGAT \\
\hline 14. SPPV_10700-99_Sheep_Turkey_NC_004002 & TG TAAATTTTTTTTTAAAAGATAAAAAAGATGAT \\
\hline 15. SPPV_Tunisia_14/15_Sheep_Tunisia_KT 964233 & TG TAAATTTTTTTTTAAAAGATAAAAAAGATGAT \\
\hline 16. SPPV_Zabaikalsk_Sheep_Russia_KC847056 & TG TAAATTTTTTTTTAAAAGATAAAAAAGAT. \\
\hline 17. GTPV_Uttarkashi_p61_Goat_India_AY382869 & TGTAAAATTTTTTTTAAAAGATAAAAAAGAT \\
\hline 18. GTPV_Akola/2008_P2_Goat_India_FJ748488 & TGTAAAATTTTTTTTAAAAGATAAAAAAGAT \\
\hline 19. GTPV_Mukteswar/1946_P4_Goat_India_AY159333 & TG TAAAATTTTTTTTAAAAGATAAAAAAGAT \\
\hline 20. GTPV_Jammu_Kashmir/Sheep/27_Sheep_India_KF 468758 & TG TAAAATTTTTTTTAAAAGATAAAAAAGAT \\
\hline 21. GTPV_Jammu_Kashmir/Goat27_Goat_India_KF468757 & T G TAAAATTTTTTT TAAAAGATAAAAAAGA \\
\hline 22. GTPV_Maharashtra/Goat/19_Goat_KF468762 & TG TAAAATTTTTTTTAAAAGATAAAAAAGA \\
\hline 23. GTPV_Maharashtra/Sheep/19_Sheep_India_KF468759 & TG TAAAATTTTTTTTAAAAGATAAGAAAGAT \\
\hline 24. GTPV_28TN/15_Goat_India_Kr508697 & TG TAAAATTTTTTTTAAAAGATAAAAAAGA \\
\hline 25. GTPV12NWB/10_Goat_India_KY614170 & TG TAAAATTTTTTTTAAAAGATAAAAAAGA \\
\hline 26. GTPV_Thiruvarur_Goat_India_KY 389314 & TG TAAAATTTTTTTTAAAAGATAAAAAAGAT \\
\hline 27. GTPV_QjCQ_Goat_China_KJ026557 & TG TAAAATTTTTTTTAAAAGATAAAAAAGAT \\
\hline 28. GTPV_Yemen_(Sanaa/1983)_Goat_Yemen_EU625262 & TG TAAATTTTTTTTTAAAAGATAAAAAAGAT- \\
\hline 29. GTPV_Viet_Nam_(Ninh_Thuan/2005)_Goat_Viet_Nam_EU625263 & TG TAAAATTTTTTTTAAAAGATAAAAAAGAT- \\
\hline 30. GTPV_GPV/GanS/2009/China_NA_China_HM572331 & TGTAAAATTTTTTTTAAAAGATAAAAAAGAT \\
\hline 31. GTPV_vaccine_strain_NA_China_AY881707 & TG TAAAATTTTTTTTAAAAGATAAAAAAGAT \\
\hline 32. GTPV_s1_NA_China_EF522176 & TG TAAAATTTTTT TAAAAGATAAAAAAGAT- - A TCAGTTTATCATATAAGTTCC \\
\hline 33. GTPV_GS-V1_Vaccine_NA_China_JN602370 & TG TAAAATTTTTTTTAAAAGATAAAAAAGATWA TCAGTTTATCATATAAGTTCC \\
\hline 34. GTPV/HuB/2009/China_Goat_China_JN596275 & TG TAAAATTTTTTTTAAAAGATAAAAAAGATWA TCAGTTTATCATATAAGTTCC \\
\hline 35. GTPV_G20-LKV_Vaccine_strain_Kazakhstan_- & T G TAAATTTTTTTTTAAAAGATAAAAAAGA \\
\hline 36. GTPV_Pellor_Goat_Kazakhstan_NC_004003 & T G TAAATTTTTTTTTAAAAGATAAAAAAGAT \\
\hline 37. GTPV_Gorgar & \\
\hline
\end{tabular}

Figure-4: Nucleotide (nt) variation between sheeppox virus (SPPV) and goatpox virus (GTPV) viruses: Presence of three $\mathrm{nt}$ at 163:G, 164:A, and 165:T positions in SPPV, which are deleted in GTPV gene encoding for major envelope protein (P32).

\section{Results and Discussion}

Sheeppox and goatpox diseases of the Capripox genus are enzootic in India and are accountable for high economic losses due to high morbidity and mortality. The sheeppox disease outbreaks were reported in two separate mixed (sheep and goats) flocks from two different villages under Kanakapura Tehsil, Ramanagara district of Karnataka were included in the study. The morbidity and mortality rate recorded were higher in Gerahalli with $75 \%(60 / 80)$ and 55\% (33/60) compared to Horalagallu village with $66.66 \%(40 / 60)$ and $52.5 \%(21 / 40)$, respectively (Table-2). The variable morbidity and mortality rates are mainly attributed to host species and virus isolate, pox disease [8]. On personal interaction with the farming community, it was learned that the pox outbreaks are rarely encountered. However, the outbreaks coincide with less rainfall and fodder shortage during which there is very probability of migration of flocks. Due to the less prevalence of pox disease in the past, the farmers did not practice regular vaccination. However, in spite of community grazing and water facility, the other flocks in the villages did not report the disease due to the practice of regular vaccination. During the present outbreak, only sheep were affected even though in both villages, the herds affected had goats along with sheep. Off late, the SPPVs and GTPVs infections are being reported with host specificity [22], whereas some strains equally infect both the species, but the disease severity and pattern caused by the same isolate may vary between sheep and goats $[23,24]$.

In both, the outbreaks, clinical signs such as fever, dullness, anorexia, vesicles, loss of wool, alofacia, mucopurulent nasal/oral discharge, edema of eyelids, conjunctivitis, nodules, and pox lesions were observed in the hairless region of the body including muzzle, udder, teats, ventral part of the tail, lips, and on ears were recorded with variable degree similar to earlier reports [23,25]. Clinical samples (Nasal;4/6, Scab;25/25) were found positive for the partial P32 gene by preliminary screening by PCR [18]. The polled samples from both nasal and scabs showed characteristic cytopathic changes such as rounding of cells, clumping, and finally detachment of cells from the surface in Vero cells (Figure-1). The CPE was observed after sixth blind passage, i.e, seventh passage in Vero cells. The growth of the virus was first confirmed by genus-specific PCR with a specific amplicon of size $237 \mathrm{bp}$. Further to know species of virus isolates, two isolates (one for each outbreak) were subjected for complete ORF of P32 gene PCR (Figure-2), followed by sequencing. The species of the virus was confirmed as SPPV by sequence analysis.

The complete P32 gene sequences obtained were annotated at $972 \mathrm{nts}$ using online tool BLAST-n and GenBank accessions were obtained (MK607146 and 
MN639777). The sequence analysis revealed both the isolates belong to SPPV with the presence of SPPV specific nts and amino acid (aa) as compared to GTPV. The phylogenetic analysis showed that both the sequences from present outbreaks were grouped into SPPVs clade compared to other poxviruses. There were two separate clades of CaPVs with SPPV isolates forming separate groups from that of GTPV isolates (Figure-3). The P32 sequence analysis of both SPPVs and GTPVs revealed the presence of three specific nts for SPPV, which is deleted in the case of GTPVs (Figure-4), confirming the present outbreaks were due to SPPV. The multiple alignments revealed that isolates of both outbreaks shared $100 \%$ with each other at nt and aa levels indicating same strain of SPPV causing the outbreaks in both the villages. This was also supported by the observation of farmers that the flocks share common grazing land and water during summer session along with migratory flocks. The isolates also a very high similarity with previously isolated SPPVs at the nt and aa from Karnataka, followed by India. On the global level, the present isolates were closely related to SPPV isolates of China as reported earlier $[18,26]$.

\section{Conclusion}

The present outbreaks were attributed to the same strain of SPPV based on clinical, virus isolation, host specificity, and sequence analysis. The present kind of outbreaks with high morbidity and mortality warrants the need for prevention and control of sheep and goatpox disease through regular vaccination and monitoring the host specificity of CaPVs for the improvement of specific homologous vaccines in future for preventing the economic loss to the farming community.

\section{Authors' Contributions}

The present study is the part of KS's Ph.D., dissertation work. KS, GBMR, and YR visited the field, collected the samples, KS and RA carried out the laboratory experiment, SK drafted the manuscript. GBMR, PR, and YR designed the work, provided guidance with overall monitoring, analyzed the data and edited the manuscript. The final manuscript was drafted, read, and approved by all the authors.

\section{Acknowledgments}

The authors wish to thank Indian Council of Agricultural Research Institute (ICAR), New Delhi, India, for encouragement and support. This part of the research work was funded from DBT-Twinning Pox project (F. No-6-22(3)/DBT Twinning/ NIVEDI//2013-14/4814-4820 dated. 03.12.2013), Department of Biotechnology, Government of India. The authors also thank the Director of ICAR-National Institute of Veterinary Epidemiology and Disease Informatics and also staff for constant support and timely help. We are grateful to the veterinarians and farmers who helped in sample collection.

\section{Competing Interests}

The authors declare that they have no competing interests.

\section{Publisher's Note}

Veterinary World remains neutral with regard to jurisdictional claims in published institutional affiliation.

\section{References}

1. Provisional Key Results $20^{\text {th }}$ Livestock Census. (2019) Department of Animal Husbandry and Dairying. Available from: http://www.dahd.nic.in/division/provisional-key-results-20th-livestock-census. Last accessed on 5-11-2019.

2. Babiuk, S., Bowden, T., Boyle, D., Wallace, D. and Kitching, R. (2008) Capripox viruses: An emerging worldwide threat to sheep, goats and cattle. Transbound. Emerg. Dis., 55(7): 263-272.

3. Yeruham, I., Yadin, H., Van Ham, M., Bumbarov, V., Soham, A. and Perl, S. (2007) Economic and epidemiological aspects of an outbreak of sheeppox in a dairy sheep flock. Vet. Rec., 160(7): 236-237.

4. Murphy, F., Faquet, C., Bishop, D., Ghabrial, S., Jarvis, A., Martelli, G., Mayo, M. and Summers, M. (1995) Virus taxonomy: $6^{\text {th }}$ report of the International Committee on Taxonomy of Viruses. Arch. Virol. Suppl. 10(1):85-86.

5. Buller, R.M., Arif, B.M., Black, D.N., Dumbell, K.R., Esposito, J.J., Lefkowitz, E.J., McFadden, G., Moss, B., Mercer, A.A., Moyer, R.W., Skinner, M.A. and Tripathy, D.N. (2005) Poxviridae. In: Fauquet, C.M., Mayo, M.A., Maniloff, J., Desselberger, U. and Ball, L.A., editors. Virus Taxonomy: Eighth Report of the International Committee on the Taxonomy of Viruses. Elsevier Academic Press, Oxford. p117-133.

6. Venkatesan, G., Balamurugan, V., Singh, R.K. and Bhanuprakash, V. (2010) Goat pox virus isolated from an outbreak at Akola, Maharashtra (India) phylogenetically related to Chinese strain. Trop. Anim. Health Prod., 42(6): 1053-1056.

7. Madhavan, A., Venkatesan, G. and Kumar, A. (2016) Capri poxviruses of small ruminants: Current updates and future perspectives. Asian J. Anim. Vet. Adv., 11(12): 757-770.

8. Bhanuprakash, V., Indrani, B.K., Hosamani, M. and Singh, R.K. (2006b) The current status of sheep pox disease. Comp. Immunol. Microbiol. Infect. Dis., 29(1): 27-60.

9. Bhanuprakash, V., Hosamani, M. and Singh, R. (2011) Prospects of control and eradication of capripox from the Indian subcontinent: A perspective. Antiviral Res., 91(3): 225-232.

10. Tulman, E.R., Afonso, C.L., Lu, Z., Zsak, L., Sur, J.H., Sandybaev, N.T., Kerembekova, U.Z., Zaitsev, V.L., Kutish, G.F. and Rock, D.L. (2002) The genomes of sheeppox and goatpox viruses. J. Virol. 76(12): 6054-6061.

11. Chand, P. (1992) Molecular and Immunological Characterization of a Major Envelope Protein of Capripoxvirus. Vol. 227. Ph.D. Thesis, University Surrey, UK. p187-196.

12. Yan, X.M., Chu, Y.F., Wu, G.H., Zhao, Z.X., Li, J., Zhu, H.X. and Zhang, Q. (2012) An outbreak of sheep pox associated with goat poxvirus in Gansu province of China. Vet. Microbiol., 156(3-4): 425-428.

13. Mirzaie, K., Barani, S.M. and Bokaie, S. (2015) A review of sheep pox and goat pox: Perspective of their control and eradication in Iran. J. Adv. Vet. Anim. Res., 2(4): 373-381.

14. Balinsky, C.A., Delhon, G., Smoliga, G., Prarat, M., French, R.A., Geary, S.J., Rock, D. L. and Rodriguez, L.L. (2008) Rapid preclinical detection of sheeppox virus by a real-time PCR assay. J. Clin. Microbiol., 46(2): 438-442.

15. Le Goff, C., Lamien, C.E., Fakhfakh, E., Chadeyras, A., 
Aba-Adulugba, E., Libeau, G., Tuppurainen, E., Wallace, D.B., Adam, T., Silber, R., Gulyaz, V., Madani, H., Caufour, P., Hammami, S., Diallo, A. and Albina, E. (2009) Capripoxvirus G-protein coupled chemokine receptor: A host-range gene suitable for virus animal origin discrimination. J. Gen. Virol., 90(Pt 8): 1967-1977.

16. Lamien, C.E., Le Goff, C., Silber, R., Wallace, D.B., Gulyaz, V., Tuppurainen, E., Madani, H., Caufour, P., Adam, T., El Harrak, M., Luckins, A.G., Albina, E. and Diallo, A. (2011a) Use of the capripoxvirus homologue of Vaccinia virus $30 \mathrm{kDa}$ RNA polymerase subunit (RPO30) gene as a novel diagnostic and genotyping target: Development of a classical PCR method to differentiate goat poxvirus from sheep poxvirus. Vet. Microbiol., 149(1-2): 30-39.

17. Santhamani, R., Yogisharadhya, R., Venkatesan, G., Shivachandra, S.B., Pandey, A.B. and Ramakrishnan, M.A. (2014) Molecular characterization of Indian sheeppox and goatpox viruses based on RPO30 and GPCR genes. Virus Genes, 49(2): 286-91.

18. Manjunathareddy, G.B., Sumana, K., Babu, S., Yadav, J., Balamurugan, V., Hemadri, D., Patil, S.S., Suresh, K.P., Gajendragad, M.R. and Rahman, H. (2015) Pathological and molecular characterization of capripox virus outbreak in sheep and goats in Karnataka. Indian J. Vet. Pathol., 39(1): 11-14.

19. Heine, H.G., Stevens, M.P., Foord, A.J. and Boyle, D.B. (1999) A capripoxvirus detection PCR and antibody ELISA based on the major antigen P32 the homolog of the Vaccinia virus $\mathrm{H} 3 \mathrm{~L}$ gene. J. Immunol. Meth., 227(1-2): 187-196.
20. Tamura, K., Nei, M. and Kumar, S. (2004) Prospects for inferring very large phylogenies by using the neighbor-joining method. Proc. Natl. Acad. Sci. USA, 101(30): 11030-11035.

21. Kumar, S., Stecher, G., Li, M., Knyaz, C. and Tamura, K. (2018) MEGA X: Molecular evolutionary genetics analysis across computing platforms. Mol. Biol. Evol., 35(6): $1547-1549$.

22. Manjunathareddy, G.B., Sumana, K., Apsana, R., Yogisharadhya, R., Prajapati, A., Patil, S.S. and Balamuragan, V. (2017) Investigation of malignant form of sheep pox outbreak in fattening lambs in Mandya, Karnataka India. J. Vet. Pathol., 41(3): 184-188.

23. Verma, S., Verma, L.K., Gupta, V.K., Katoch, V.C., Dogra, V., Pal, B. and Sharma, M. (2011) Emerging capripoxvirus disease outbreaks in Himachal Pradesh, a Northern state of India, Transbound. Emerg. Dis., 58(1): 79-85.

24. Ramakrishnan, M.A., Santhamani, R. and Pandey, A.B. (2017) Capripox outbreak in a mixed flock of sheep and goats in India. Transbound. Emerg. Dis., 64(1): 27-30.

25. Singh, R., Chandra, D., Singh, K.P., Hosamani, M., Singh, R.K. and Chauhan, R.S. (2007) Epidemiological investigation of sheep pox outbreaks in Rajasthan. Indian $J$. Vet. Pathol., 31(2): 120-125.

26. Bhanuprakash, V., Venkatesan, G., Balamurugan, V., Hosamani, M., Yogisharadhya, R., Chauhan, R.S, Pande, A., Mondal, B. and Singh, R.K. (2010) Pox outbreaks in sheep and goats at Makhdoom (Uttar Pradesh), India: Evidence of sheeppox virus infection in goats. Transbound. Emerg. Dis., 57(5): 375-382. 